\title{
Making a Hidden Collection Visible: Columbia's Collection of Muslim World Manuscripts
}

\author{
Zeinab Azarbadegan \\ PhD Candidate, Department of History, Columbia University, \\ New York, NY, USA \\ zaa2117@columbia.edu \\ Mohammad Sadegh Ansari \\ Assistant Professor, Department of History, SUNY Geneseo, \\ New York, NY, USA \\ mansari@geneseo.edu
}

\section{Introduction}

In the pre-modern world, manuscripts were the main media for the production and circulation of knowledge. Scholars can learn much from these sources about the times by-gone, not simply through analyzing their content, but by examining them as physical remnants of the past. Manuscripts shed light on the language, culture, beliefs, knowledge, religion, and practices of past societies no longer otherwise accessible to us. Their use becomes even more important when studying the history of the Islamic world, considering the enormous change these societies have undergone in the past two centuries. Unfortunately, scholars have neglected to pay due attention to these items. Columbia University's collections are an example of such an oversight, where the collection was scarcely cataloged for over eighty years. The Muslim World Manuscripts Project initiated a collaborative cataloging project including a group of scholars and spearheaded by librarians_-specially Maria Oldal, Jane Rodgers Siegel, and Peter Magiersky.

As a second attempt to bring more attention to these collections, we, Zeinab Azarbadegan and Mohammad Sadegh Ansari, along with Manan Ahmed and Mahmood Gharavi organized a conference in February 2017. "Rediscovering Words and Worlds: Arabic Script Collections at Columbia University" brought together scholars and librarians from various disciplines and institutions to 
discuss the state of the field of Islamic manuscript studies and consider some unique items in the Columbia collection through workshops. The conference culminated in drafting a proposal by Columbia University's Rare Book and Manuscript Library (RMBL) under the leadership of Sean Quimby to apply for a grant to digitize a portion of the collection and make it available to the public in cooperation with four other libraries and universities. The Manuscripts of the Muslim World Project, a partnership between the Columbia University Libraries, the Libraries of the University of Pennsylvania, Haverford College, Bryn Mawr College, and the Free Library of Philadelphia, was awarded a CLIR Mellon grant for Digitizing Hidden Collections and Archives in 2017, with more than five hundred items currently digitized and accessible.

This special issue is the next stage in the scholarly efforts to further publicize the contents and importance of the collections. We hope this will prompt not only further exploration of the collection by the academic community, but also an examination of histories of acquisition of these items in North American and European libraries. The history of the Columbia manuscript collections as well as the context in which the collections were built, including the people behind the collections (donors, scholars, faculty and students) in the century prior to the digitization project is explored in the first contribution to this special issue by Columbia University librarians, Kaoukab Chebaro and Jane Rodgers Siegel.

There are five contributions by scholars from across disciplinary, regional, and linguistic specialisms, each considering one specific item from the collections. They explore the three themes and questions of (1) authority and originality, through studies of commentary, translation, and copying practices; (2) transmission of knowledge from one generation or regional culture to another exposing varying vectors and networks of transmission by exploring different modes of textual reproduction, such as manuscripts and lithographs; (3) history of science, where the strength of the Columbia collections lies in the richness and variety of the scientific treatises it houses.

Avinoam Shalem examines one of the fifty copies of 'Uthmān's Qur'ān codex from Samarkand, namely one of the so-called Pissareff Qur'ān codices of 1905 held at RBML, considering its specific status in the grey zone between reproduction and copy. Alexandre Roberts discusses the production of mathematical knowledge in the Islamic world, analyzing a treatise composed by a member of the "minority" religious group of Sabians, Jābir ibn Ibrāhīm al-Ṣābī, and two commentaries on it, kept in the same codex. Roberts contextualizes the role of these treatises in the mathematical tradition and within the manuscript itself, highlighting the processes of education and learning in the premodern Islamic world. 
A. Tunç Şen examines an early-seventeenth century copy of a popular Ottoman compendium of sciences originally composed by $\mathrm{Nev}^{c} \bar{i}$ Efendi (d. 1599) in the early 1570s, which includes abundant marginal notes. He pays close attention to discussing these marginal notes that present intriguing insights into the questions of what a published work meant in the age of manuscripts, and how the continuous interventions made by the author, the copyists, and the readers on the copies of a single text enrich as well as obscure the authentic contents of the "published" version. Trevor Brabyn and Mohammad Sadegh Ansari look at one of the manuscripts of a collection (majmǘah) of treatises compiled in a codex for a Qajar prince in early nineteenth-century Iran. Through studying the text and the context of the manuscript in question, the authors shed light on one of the earliest examples (if not the earliest) of the introduction of Copernican astronomy to Qajar Iran, interestingly not via Western and westernized routes and scholars, but via a series of earlier IndoPersian treatises on the subject.

Zeinab Azarbadegan discusses Jäm-i Jam, a lithograph published in Tehran in 1856 and housed in Columbia's offsite storage. She demonstrates the dual importance of this book in geographic knowledge production and as part of the library of Sa'ìd Nafisisi, one of the most prominent Iranian scholars of Persian literature. Methodologically, her paper offers various ways to study a single lithograph to decipher larger historical processes in histories of education, translation, and print. The special issue concludes with an afterword written by Marwa Elshakry on the importance of conducting archival research on manuscript collections and the role of such collections held at North American and European libraries and archives in furthering the fields of intellectual history, history of the book, and history of science.

This collaborative project would not have been possible in its many stages without the help, support, and sponsorship of numerous individuals and institutions within Columbia University, including but not limited to: RBML; Middle East Institute, specially Brinkley Messick; Office of the Dean of Social Science, Faculty of Arts and Sciences; Office of the University Librarian, specially Ann Thornton; Center for International History, Center for Science and Society, specially Pamela Smith; Institute of Religion, Culture, and Public Life (IRCPL); Department of Anthropology; Department of History; Department of Art History and Archaeology; Department of Middle Eastern, South Asian, and African Studies (MEsAAs). Outside Columbia, this project is indebted to Hossein Modarressi, Kelly Tuttle, and the Andrew W. Mellon Foundation. 